\title{
THE DEVELOPMENT OF CONCEPTUAL MODEL ON INDONESIAN CONSUMER BEHAVIOR TOWARDS HALAL-LABELED DRUGS
}

\author{
Anggi Triantoro*), Ujang Sumarwan**), and Sufrin Hannan***) \\ *) School of Business, IPB University \\ Jl. Raya Pajajaran, Bogor 16151, Indonesia \\ ${ }^{* *}$ Department of Family and Consumer Sciences, Faculty of Human Ecology, IPB University \\ Jl. Kamper, Babakan, Dramaga, Bogor 16680, Indonesia \\ ${ }^{* * *)}$ Graduate School, Pakuan University \\ Jl. Pakuan, Bogor 16143, Indonesia
}

\begin{abstract}
There were still very few halal-labeled drugs in Indonesia, which can be caused by low consumer demand. Every consumer has perceived risk on a product, including halallabeled drugs. Only consumers with good preference towards halal-labeled drugs are willing to take risks by choosing halal-labeled drugs to obtain peace of mind, which is manifested as satisfaction and trust. This study aims to identify how perceived risk on Indonesian people could influence satisfaction and trust, which leads to intention to use and intention to recommend halal-labeled drugs. Data were obtained from 332 Indonesian respondents aged at least 17 years old who were collected by convenience using social media which were then processed by PLS-SEM. This study found that perceived risk naturally can influence satisfaction, which leads to intention to use supported by knowledge and previous use experience, leading to intention to recommend. Meanwhile, perceived risk supported by knowledge can affect trust, which in turn can influence intention to use, and then leads to intention to recommend. In conclusion, knowledge and previous use experience are supporting factors which are required to trigger the consumer preference toward halal-labeled drugs.
\end{abstract}

Keywords: halal drugs, intention, perceived risk, satisfaction, trust

Abstrak: Jumlah obat berlabel halal yang masih sangat sedikit di Indonesia dapat disebabkan oleh rendahnya permintaan konsumen. Setiap konsumen memiliki persepsi risiko pada suatu produk, termasuk obat berlabel halal. Hanya konsumen dengan preferensi terhadap obat berlabel halal yang baik saja yang bersedia mengambil risiko memilih obat berlabel halal untuk memperoleh ketenangan jiwa yang dimanifestasikan sebagai rasa puas dan percaya. Penelitian ini bertujuan untuk mengetahui bagaimana persepsi risiko masyarakat Indonesia dapat memengaruhi kepuasan dan kepercayaan yang berujung pada niat menggunakan dan niat merekomendasikan obat berlabel halal. Data diperoleh dari 332 responden Indonesia berusia minimal 17 tahun yang diambil secara kebetulan melalui media sosial yang selanjutnya diolah dengan PLS-SEM. Penelitian ini menemukan bahwa persepsi risiko secara alamiah sudah dapat memengaruhi kepuasan, yang dapat berlanjut ke niat menggunakan dengan adanya pengetahuan dan pengalaman sebelumnya, kemudian berujung pada niat merekomendasikan. Sementara itu, persepsi risiko dengan adanya pengetahuan dapat memengaruhi kepercayaan, yang selanjutnya dapat memengaruhi niat menggunakan, kemudian berujung pada niat merekomendasikan. Dapat disimpulkan bahwa pengetahuan dan pengalaman sebelumnya merupakan faktor pendukung yang dibutuhkan untuk memicu preferensi konsumen terhadap obat berlabel halal.

Kata kunci: obat halal, niat, persepsi risiko, kepuasan, kepercayaan

${ }^{1}$ Corresponding author:

Email: anggi.triantoro@gmail.com 


\section{INTRODUCTION}

Through Law No. 33 Year 2014, the government declared that every drug marketed in Indonesia should be halal-certified since 17 October 2019 (Presiden RI, 2014). However, based on the assessment through the database of Indonesian Food and Drug Administration (BPOM RI) and Indonesian Council of Ulama (MUI) on 12 October 2019, the number of halal-certified drugs in Indonesia were only 4.95\% (BPOM RI, 2019; LPPOM MUI, 2019). Furthermore, Ministry of Religious Affairs released a Regulation of Minister of Religious Affairs No. 26 Year 2019 to enact the phasing of halal certification obligation for drug products started from 17 October 2021 until 17 October 2029 for an over-thecounter drug, or until 17 October 2034 for prescription drug (except psychotropics) as preparation time (Menag RI, 2019).

The effectiveness of implementing the Halal Assurance System (HAS) is still relatively low, as it has yet to be implemented widely (Nafis, 2019). Aside from the challenges to implement the HAS, the low demand for halal drugs from consumers can be one factor that causes the pharmaceutical industry's reluctance to immediately implement the halal certification (Annabi and Wada, 2016). If consumer demand is high, the pharmaceutical industry may immediately rush to fulfill the demand by implementing the halal certification on all their products, no matter how hard it is. The consumer can act as a driver to increase the demand for halal-labeled drugs, thus encouraging halal certification in the pharmaceutical industry.

Currently, there are not many studies conducted to comprehensively assess how the public views and attitudes towards halal-labeled drugs, especially in Indonesia. Previous study in other countries with similar demographic aspects to Indonesia showed that generally the people in Malaysia and Nigeria do not yet have the awareness towards the use of halallabeled drugs (Annabi and Wada, 2016; Famiza et al. 2017). However, there is no established conceptual model related to halal-labeled drugs. In contrast to halal food, many studies have been conducted with several approaches. Al-Ansi et al. (2019) introduced the perceived risk concept which is formulated into a conceptual model for halal food. Every product basically has a number of risks perceived by the consumer, which can negatively impact purchasing decisions (Dowling and Staelin, 1994; Johnson et al. 2008). Refer to Al-
Ansi et al. (2019), choosing halal products can also be considered risk because it is a form of sacrifice in practicing sharia. When the consumer awareness to use halal-labeled products is high, the consumers are willing to take the risk to increase the peace of mind manifested as satisfaction and trust (Al-Ansi et al. 2019). The conceptual model of this approach can be adapted to be applied to consumer preferences towards halal-labeled drugs. The existing studies also have not discussed the factors needed to support consumer preference towards halal-labeled drugs. Therefore, the existing conceptual model is further adapted by testing several moderations, which are expected to support the model's sustainability.

This study aims to find out how the perceived risk of Indonesian people can influence satisfaction and trust, which leads to intention to use and intention to recommend. This research will determine whether Indonesian consumers are daring enough to break through the risks perceived on halal-labeled drugs through the concept of perceived risk. Their willingness to take risks can be explored, whether it has a continuous effect to the formation of satisfaction, trust, intention to use, and intention to recommend. This research is also expected to help to formulate the strategy to increase the consumer preference for halal-labeled drugs.

\section{METHODS}

Convenience sampling was applied to an Indonesian citizen aged at least 17 years old. Google Forms was used as a survey media. The questionnaire link was distributed via social media from 29 February to 3 April 2020. The respondents were welcomed to redistribute the questionnaire to others. Digital location-based advertising was also used to enhance the spread, where people within a certain radius in Jakarta area will receive the questionnaire link through short message service (SMS).

Table 1 defines the main variables, such as perceived risk, satisfaction, trust, intention to use, and intention to recommend. A five-point Likert scale started from 1 (strongly disagree) to 5 (strongly agree), is used in the measurement of these main variables. Some manifest variable questions were adapted from Lien et al. (2015) and Al-Ansi et al. (2019) with several adjustments and further development. A second-order construct of perceived risk is used to cover all seven types of risk 
since they are a multidimensional factor, each of which has a positive or negative effect (Al-Ansi et al. 2019).

The moderating variable is used to find out what factors can influence the sustainability of the proposed conceptual model. The moderating variables are knowledge, Islamic religious belief, and previous use experience on halal-labeled drugs.

Prior to main study, a pilot study on 35 respondents has already done to test the question understandability, including validity and reliability. A pilot study resulted good validity and reliability, thus no need to amend the questionnaire. Knowledge test questions specifically have been consulted with practitioners in internal halal audits and regulatory affairs. All questions must be easily understood by laypeople to improve the quality of primary data.
Partial least square structural equation modeling (PLSSEM) is chosen by considering the purpose of this research, the number of samples, and the existence of second-order construct. Research on consumer behavior regarding halal-labeled drugs is still very rare, and there is no specific established model to represent the condition in Indonesia. This approach is considered to be appropriate as the proposed model predictor. The total samples of 332 respondents can be considered small, thus more appropriate to be analyzed using the PLS-SEM approach. In addition, the PLSSEM approach is also suitable to analyze a complex model with the presence of mediator and second-order construct (Chin and Newsted, 1999).

Several previous studies have been assessed to propose the effect between variables with some adaptations. Knowledge, Islamic religious belief, and previous use experience as moderating variables. A conceptual model can be proposed, as shown in Figure 1.

Table 1. List of main variables

\begin{tabular}{|c|c|c|c|}
\hline $\begin{array}{l}\text { Latent } \\
\text { Variables }\end{array}$ & Manifest Variables & Notation & $\begin{array}{l}\text { Factor } \\
\text { Loading }\end{array}$ \\
\hline \multicolumn{4}{|l|}{ Perceived risk } \\
\hline \multirow{5}{*}{$\begin{array}{l}\text { Health risk } \\
\text { (HEA) }\end{array}$} & Concerns that a disease cannot be cured soon if using drugs without halal label & HEA1 & 0.906 \\
\hline & Concerns that a disease will get worse if using drugs without halal label & HEA2 & 0.927 \\
\hline & Concerns to be more susceptible to disease if using drugs without halal label & HEA3 & 0.924 \\
\hline & Concerns that using drugs without halal label are not healthy & HEA4 & 0.933 \\
\hline & Concerns that using drugs without halal label are dangerous to health & HEA5 & 0.906 \\
\hline \multirow{5}{*}{$\begin{array}{l}\text { Psychological } \\
\text { risk (PSY) }\end{array}$} & Concerns to get anxiety when using drugs without halal label & PSY1 & 0.905 \\
\hline & Concerns to have an uncomfortable feeling when using drugs without halal label & PSY2 & 0.924 \\
\hline & Concerns to get stressed when using drugs without halal label & PSY3 & 0.900 \\
\hline & Concerns to have guilty feeling when using drugs without halal label & PSY4 & 0.924 \\
\hline & Concerns to have regret when using drugs without halal label & PSY5 & 0.928 \\
\hline \multirow{4}{*}{$\begin{array}{l}\text { Social risk } \\
\text { (SOC) }\end{array}$} & Concerns to be considered bad by others if only willing to use halal-labeled drugs & SOC1 & 0.919 \\
\hline & Concerns to be ostracized by others if only willing to use halal-labeled drugs & SOC2 & 0.938 \\
\hline & Concerns to be gossiped by others if only willing to use halal-labeled drugs & SOC3 & 0.910 \\
\hline & $\begin{array}{l}\text { Concerns to get excessive advices by others if only willing to use halal-labeled } \\
\text { drugs }\end{array}$ & SOC4 & 0.826 \\
\hline \multirow{5}{*}{$\begin{array}{l}\text { Quality risk } \\
\text { (QUA) }\end{array}$} & Concerns to receive poor quality drugs if there is no halal label & QUA1 & 0.852 \\
\hline & Feelings that halal label shows the guaranteed quality & QUA2 & 0.760 \\
\hline & Concerns that the drugs will be more easily damaged if there is no halal label & QUA3 & 0.859 \\
\hline & Confidence not to complain on the quality of halal-labeled drugs & QUA4 & 0.750 \\
\hline & $\begin{array}{l}\text { Confidence that the quality of halal-labeled drugs is still good, although the drugs } \\
\text { are broken (e.g. cracked tablet) }\end{array}$ & QUA5 & 0.636 \\
\hline
\end{tabular}


Table 1. List of main variables

\begin{tabular}{|c|c|c|c|}
\hline $\begin{array}{l}\text { Latent } \\
\text { Variables }\end{array}$ & Manifest Variables & Notation & $\begin{array}{l}\text { Factor } \\
\text { Loading }\end{array}$ \\
\hline \multirow{4}{*}{$\begin{array}{l}\text { Financial risk } \\
\text { (FIN) }\end{array}$} & Concerns that halal-labeled drugs are more expensive than drugs without halal label & FIN1 & 0.813 \\
\hline & Concerns that buying halal-labeled drugs will cost an unexpected additional expense & FIN2 & 0.931 \\
\hline & Concerns that using halal-labeled drugs will disrupt my long-term financial & FIN3 & 0.920 \\
\hline & $\begin{array}{l}\text { Concerns not having enough money, if always using halal-labeled drugs for a long- } \\
\text { term period }\end{array}$ & FIN4 & 0.910 \\
\hline \multirow[t]{4}{*}{$\begin{array}{l}\text { Time-loss risk } \\
\text { (TIM) }\end{array}$} & $\begin{array}{l}\text { Concerns to have working time disrupted when trying to find and obtain halal- } \\
\text { labeled drugs }\end{array}$ & TIM1 & 0.928 \\
\hline & Concerns to have less family time when trying to find and obtain halal-labeled drugs & TIM2 & 0.952 \\
\hline & $\begin{array}{l}\text { Concerns to have less resting time when trying to find and obtain halal-labeled } \\
\text { drugs }\end{array}$ & TIM3 & 0.955 \\
\hline & $\begin{array}{l}\text { Concerns to more time taken in planning to buy halal-labeled drugs than drugs } \\
\text { without halal label }\end{array}$ & TIM4 & 0.878 \\
\hline \multirow{10}{*}{$\begin{array}{l}\text { Religious } \\
\text { belief risk } \\
\text { (REL) }\end{array}$} & Concerns that not using halal-labeled drugs will infringe Islamic religious teachings* & REL1 & 0.895 \\
\hline & $\begin{array}{l}\text { Having no concerns on using halal-labeled drugs, although halal aspect is not part } \\
\text { of current religious belief }{ }^{* *}\end{array}$ & & \\
\hline & Sinful feelings when not using halal-labeled drugs* & REL2 & 0.930 \\
\hline & $\begin{array}{l}\text { Thought that halal logo on drug labeling does not bother when using halal-labeled } \\
\text { drugs }^{* *}\end{array}$ & & \\
\hline & Concerns that the worship will not be accepted if using drugs without halal label* & REL3 & 0.893 \\
\hline & $\begin{array}{l}\text { Willingness to consume halal-labeled drugs, which are manufactured in line with } \\
\text { sharia** }^{* *}\end{array}$ & & \\
\hline & $\begin{array}{l}\text { Concerns that the voiced prays will not be answered by the God if not using halal- } \\
\text { labeled drugs* }\end{array}$ & REL4 & 0.867 \\
\hline & $\begin{array}{l}\text { Feelings that consuming halal-labeled drugs will not weaken current religious } \\
\text { belief }^{* *}\end{array}$ & & \\
\hline & $\begin{array}{l}\text { Concerns that drugs are not halal, if not paying good attention on halal logo when } \\
\text { buying or using drugs* }\end{array}$ & REL5 & 0.754 \\
\hline & $\begin{array}{l}\text { Confidence that using halal-labeled drugs does not mean instilling Islamic religious } \\
\text { teachings into oneself }\end{array}$ & & \\
\hline \multirow{6}{*}{$\begin{array}{l}\text { Satisfaction } \\
\text { (SAT) }\end{array}$} & Glad on using halal-labeled drugs* & SAT1 & 0.866 \\
\hline & $\begin{array}{l}\text { Glad on using halal-labeled drugs, although halal aspect is not part of current } \\
\text { religious belief** }\end{array}$ & & \\
\hline & Satisfied with using halal-labeled drugs* & SAT2 & 0.903 \\
\hline & $\begin{array}{l}\text { Satisfied with using halal-labeled drugs, although halal aspect is not part of current } \\
\text { religious belief }{ }^{* *}\end{array}$ & & \\
\hline & Thought that halal-labeled drugs are more satisfying than those without halal label ${ }^{*}$ & SAT3 & 0.837 \\
\hline & $\begin{array}{l}\text { Thought that halal-labeled drugs are more satisfying than those without halal label, } \\
\text { although halal aspect is not part of current religious belief }\end{array}$ & & \\
\hline \multirow[t]{6}{*}{ Trust (TRU) } & Trust that halal-labeled drugs have good efficacy* & TRU1 & 0.934 \\
\hline & $\begin{array}{l}\text { Trust that halal-labeled drugs have good efficacy, although halal aspect is not part of } \\
\text { current religious belief: }\end{array}$ & & \\
\hline & Trust that halal-labeled drugs have good quality* & TRU2 & 0.945 \\
\hline & $\begin{array}{l}\text { Trust that halal-labeled drugs have good quality, although halal aspect is not part of } \\
\text { current religious belief** }\end{array}$ & & \\
\hline & Trust on the information listed in the package of halal-labeled drugs* & TRU3 & 0.801 \\
\hline & $\begin{array}{l}\text { Trust on the information listed in the package of halal-labeled drugs, although halal } \\
\text { aspect is not part of current religious belief }\end{array}$ & & \\
\hline
\end{tabular}


Table 1. List of main variables

\begin{tabular}{|c|c|c|c|}
\hline $\begin{array}{l}\text { Latent } \\
\text { Variables }\end{array}$ & Manifest Variables & Notation & $\begin{array}{l}\text { Factor } \\
\text { Loading }\end{array}$ \\
\hline \multirow{6}{*}{$\begin{array}{l}\text { Intention to } \\
\text { use (IU) }\end{array}$} & Willingness to always buy or use halal-labeled drugs ${ }^{\#}$ & IU1 & 0.910 \\
\hline & Willingness to try buying or using halal-labeled drugs later in the future ${ }^{\#}$ & & \\
\hline & Willingness to always put attention on halal logo when buying or using drugs & IU2 & 0.934 \\
\hline & $\begin{array}{l}\text { Willingness to put attention on halal logo when buying or using drugs later in the } \\
\text { future"\# }\end{array}$ & & \\
\hline & Have great desire to only buy or use halal-labeled drugs ${ }^{\#}$ & IU3 & 0.918 \\
\hline & Most likely will consider buying or using halal-labeled drugs ${ }^{\# \prime}$ & & \\
\hline \multirow{3}{*}{$\begin{array}{l}\text { Intention to } \\
\text { recommend } \\
\text { (IR) }\end{array}$} & Intention to recommend the use halal-labeled drugs to others & IR1 & 0.945 \\
\hline & Intention to inform good aspects on halal-labeled drugs to others & IR2 & 0.930 \\
\hline & $\begin{array}{l}\text { Intention to invite others (family, friends, acquaintances) always to use halal-labeled } \\
\text { drugs }\end{array}$ & IR3 & 0.941 \\
\hline
\end{tabular}

Notes:

* = Answered by Islamic respondents

** $=$ Answered by non-Islamic respondents

\# = Answered by respondents who have previously used halal-labeled drugs

\# = Answered by respondents who never have or do not know ever used halal-labeled drugs

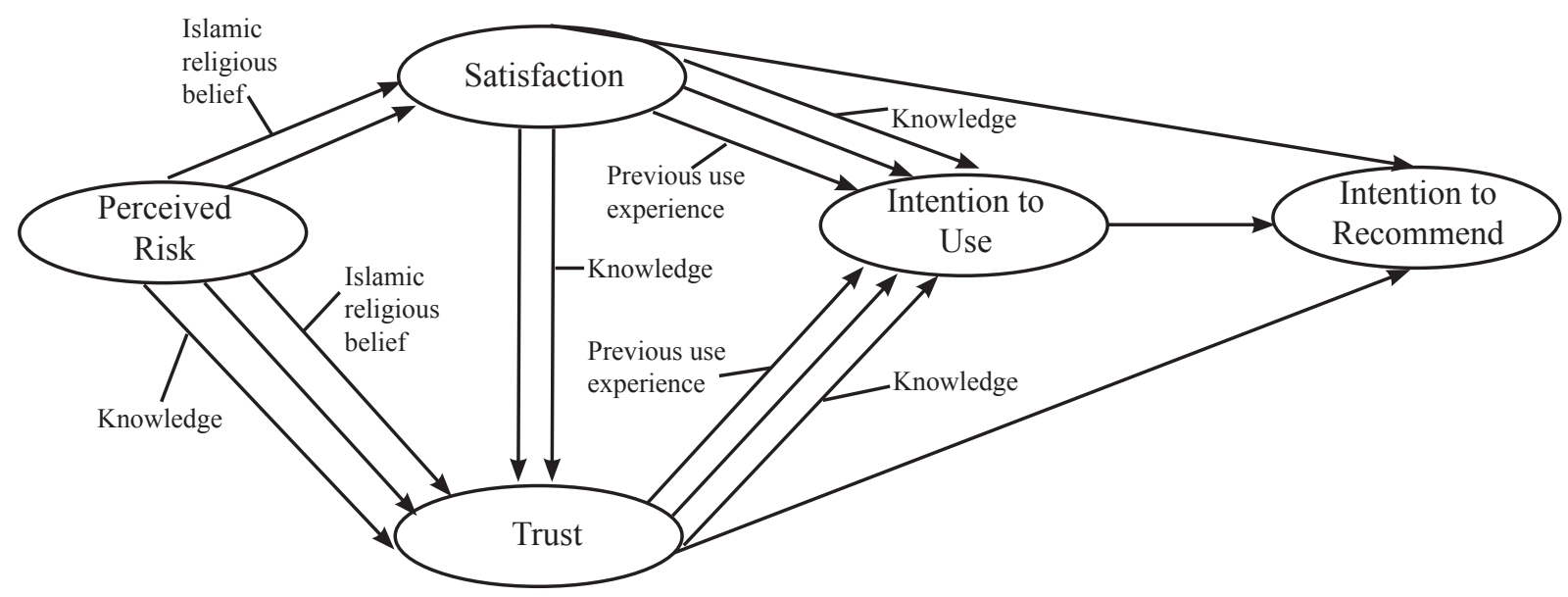

Figure 1. Conceptual model

Perceived risk can influence satisfaction and trust, depends on whether the consumer has strong motivation to break through the risk associated with a product (Johnson et al. 2008; Al-Ansi et al. 2019). Consumers who have good preference on halal-labeled drugs, should expect the existence of halal logo on the packaging. Fulfilled expectations will lead to satisfaction, even if they have not decided or purchased a product (Giese and Cote, 2000). The trust can be related to the sense of confidence that a product can provide benefits (Mowen and Minor, 2002; Dabholkar and Sheng, 2012). Islamic religious belief is used as a moderating variable to see how it may influence the model.
H1a : Perceived risk has effect to satisfaction

$\mathrm{H} 1 \mathrm{~b}$ : Perceived risk supported with Islamic religious belief, has effect to satisfaction

H2a : Perceived risk has effect to trust

$\mathrm{H} 2 \mathrm{~b}$ : Perceived risk supported with Islamic religious belief, has effect to trust

It has been well known that satisfaction can affect trust, which could lead to intention to use (Dabholkar and Sheng, 2012; Fang et al. 2014; Hannan, 2014; Semuel and Chandra, 2014; Lassoued et al. 2015; Tasin, 2017). Both satisfaction and trust have direct effect to intention to recommend (Al-Ansi et al. 2019). However, based 
on the concept of logic, before the satisfaction towards a product could trigger the intention to recommend, it should be preceded with the intention to buy or use.
$\mathrm{H} 3 \mathrm{a}$ : Satisfaction has effect to trust
$\mathrm{H} 4 \mathrm{a}$ : Satisfaction has effect to intention to use
H5 : Satisfaction has effect to intention to recommend
H6a : Trust has effect to intention to use
H7 : Trust has effect to intention to recommend
H8 : Intention to use has effect to intention to recommend

Even though the number of halal-labeled drugs marketed in Indonesia is still low, there is still the possibility that some people have bought or used halal-labeled drugs. Generally, those who have already used a product and have positive experience during the use are not reluctant to repurchase and reuse the product. Fang et al. (2014) stated that a good level of satisfaction and trust can lead to intention to repurchase a product.

$\mathrm{H} 4 \mathrm{~b}$ : Satisfaction supported with previous use experience has effect to intention to use

H6b : Trust supported with previous use experience has effect to intention to use

Preference to buy halal products is determined by the consumers' understanding level (Rambe and Afifuddin, 2012; Nofianti and Rofiqoh, 2019). Consumers' knowledge is believed to have effect on trust and

Table 2. Distribution profile of respondents

\begin{tabular}{llcc}
\hline Categories & Characteristics & Total & Percentage \\
\hline Gender & Male & 113 & $34.04 \%$ \\
& Female & 219 & $65.96 \%$ \\
Age & $17-24$ & 259 & $78.01 \%$ \\
& $25-34$ & 43 & $12.95 \%$ \\
& $35-44$ & 19 & $5.72 \%$ \\
& $45-54$ & 8 & $2.41 \%$ \\
& $55-62$ & 3 & $0.90 \%$ \\
Residence & Bogor & 229 & $68.98 \%$ \\
& Depok & 27 & $8.13 \%$ \\
& Jakarta & 27 & $8.13 \%$ \\
& Sukabumi & 17 & $5.12 \%$ \\
& Others & 32 & $9.64 \%$ \\
& Islam & 296 & $89.16 \%$ \\
& Protestant & 24 & $7.23 \%$ \\
& Hindu & 2 & $0.60 \%$ \\
\hline
\end{tabular}

intention to buy (Ekawati et al. 2014; Hannan, 2014; Kusuma and Untarini, 2014). This research uses several true-false questions to assess respondents' knowledge directly objectively. The objective knowledge will be placed as moderation to see how it can affect other variables that lead to trust and intention to use.

$\mathrm{H} 2 \mathrm{c}$ : Perceived risk supported by knowledge, has effect to trust

H3b : Satisfaction supported by knowledge, has effect to trust

$\mathrm{H} 4 \mathrm{c}$ : Satisfaction supported by knowledge, has effect to intention to use

H6c : Trust supported by knowledge, has effect to intention to use

\section{RESULTS}

\section{Demographic Characteristics}

Table 2 describes the demographic characteristics of all 332 respondents. Female respondents dominate the respondent distribution profile on gender characteristics. Most respondents are at young age, which are led by 17-24 years old. Most of the respondents live in Bogor. The religion, followed by most of the respondents are Islam. The last or currently ongoing education is mostly at the level of bachelor's degree or equivalent.

\begin{tabular}{|c|c|c|c|}
\hline Categories & Characteristics & Total & Percentage \\
\hline \multirow{10}{*}{$\begin{array}{l}\text { Current or } \\
\text { ongoing } \\
\text { education }\end{array}$} & Catholic & 2 & $0.60 \%$ \\
\hline & Buddha & 1 & $0.30 \%$ \\
\hline & Kong $\mathrm{Hu} \mathrm{Cu}$ & 1 & $0.30 \%$ \\
\hline & Others & 6 & $1.81 \%$ \\
\hline & $\begin{array}{l}\text { Senior High } \\
\text { School }\end{array}$ & 61 & $18.37 \%$ \\
\hline & $\begin{array}{l}1^{\text {st }} 3^{\text {rd }} \text { Associate's } \\
\text { Degree }\end{array}$ & 5 & $1.51 \%$ \\
\hline & $\begin{array}{l}4^{\text {th }} \text { Associate's } \\
\text { Degree or } \\
\text { Bachelor's Degree }\end{array}$ & 218 & $65.66 \%$ \\
\hline & Master's Degree & 26 & $7.83 \%$ \\
\hline & $\begin{array}{l}\text { Doctorate's } \\
\text { Degree }\end{array}$ & 3 & $0.90 \%$ \\
\hline & $\begin{array}{l}\text { Professional } \\
\text { Degree (e.g. dr., } \\
\text { apt., Ns., Ar., Ak., } \\
\text { etc.) }\end{array}$ & 19 & $5.72 \%$ \\
\hline
\end{tabular}


The basic knowledge level of drug and its halal aspects was measured directly through ten questions with several choices of answers, which are "Yes", "No" and "I don't know". The "I don't know" answer is considered as "Wrong" answer (Hicks et al. 2008). As shown in Table 3, majority of respondents still have low level of knowledge. It is interesting to see how nonIslamic respondents show relatively better knowledge level, however the small number of respondents should also be noted. The knowledge level of 17-24 years old age group is considerably poor compared to the older age.
The respondents were also asked to inform the name of the last purchased over-the-counter drugs and prescription drugs. The grouping was made based on therapeutic class as seen in Table 4. The most last purchased over-the-counter drugs is from the analgesics-antipyretics (33.59\%). As for prescription drugs, the most last purchased drugs is oral antibiotics $(2.94 \%)$.

Table 3. The basic knowledge level of drug and its halal aspects

\begin{tabular}{|c|c|c|c|c|}
\hline \multicolumn{2}{|c|}{ Categories } & Characteristics & Total & Percentage \\
\hline \multirow[t]{3}{*}{ General } & & High $($ score $>80$ ) & 31 & $9.34 \%$ \\
\hline & & Moderate (score 60-80) & 82 & $24.70 \%$ \\
\hline & & Low $($ score $<60)$ & 219 & $65.96 \%$ \\
\hline \multirow[t]{6}{*}{ Religion } & Islam & High (score $>80$ ) & 23 & $7.77 \%$ \\
\hline & & Moderate (score 60-80) & 70 & $23.65 \%$ \\
\hline & & Low $($ score $<60)$ & 203 & $68.58 \%$ \\
\hline & Non-Islam & High $($ score $>80$ ) & 8 & $22.22 \%$ \\
\hline & & Moderate (score 60-80) & 12 & $33.33 \%$ \\
\hline & & Low $($ score $<60)$ & 16 & $44.44 \%$ \\
\hline \multirow[t]{6}{*}{ Age } & $17-24$ years old & High $($ score $>80)$ & 7 & $2.70 \%$ \\
\hline & & Moderate (score 60-80) & 59 & $22.78 \%$ \\
\hline & & Low $($ score $<60)$ & 193 & $74.52 \%$ \\
\hline & $\geq 25$ years old & High $($ score $>80)$ & 24 & $32.88 \%$ \\
\hline & & Moderate (score 60-80) & 23 & $31.51 \%$ \\
\hline & & Low $($ score < 60$)$ & 26 & $35.62 \%$ \\
\hline
\end{tabular}

Table 4. The most last purchased drugs by respondents

\begin{tabular}{llcc}
\hline Categories & \multicolumn{1}{c}{ Therapeutic Class } & Total & Percentage \\
\hline Over-the-counter drugs & Analgesics-antipyretics & 129 & $33.59 \%$ \\
& Cough and/or flu drugs & 70 & $18.23 \%$ \\
& Antacids & 29 & $7.55 \%$ \\
& Others & 156 & $40.63 \%$ \\
\multirow{3}{*}{ Prescription drugs } & Oral antibiotics & 10 & $2.94 \%$ \\
& Flu drugs & 8 & $2.35 \%$ \\
& Opioid analgesics & 6 & $1.76 \%$ \\
& Non-steroidal antiinflammatory drugs & 6 & $1.76 \%$ \\
& Others & 310 & $91.18 \%$ \\
\hline
\end{tabular}




\section{Model Evaluation}

According to measurement model evaluation, all variables show good item reliability by observing the factor loading. The lowest factor loading is 0.636 which belongs to QUA5. However, minimum value of 0.5 is still acceptable as long other indicators in the same latent variable have high factor loading value (Chin, 1998). Average variance extracted (AVE) value of all variables (min. 0.602, max. 0.882) has met the minimum requirement which should not less than 0.5 (Fornell and Larcker, 1981). The model also has no issue with discriminant validity since all factor loading value of each indicator have higher correlation with its latent variable, than with the other latent variables. The model also has good reliability since both Cronbach's alpha (min. 0.832, max. 0.954) and composite reliability (CR) (min. 0.882, max. 0.965) has met the requirement in which the minimum value must be 0.7 (Barclay et al. 1995).

Based on the structural model evaluation, coefficient of determination $\left(\mathrm{R}^{2}\right)$ shows the value ranging from 0.285 to 0.583 for dependent variables. Using value of $\mathrm{R}^{2}$ from each dependent variable, the calculation of predictive relevance $\left(\mathrm{Q}^{2}\right)$ shows a value of 0.935 , which means that exogenous variables explain $93.5 \%$ of endogenous variables variance. The goodness-of-fit (GoF) is then determined from the value of AVE and $\mathrm{R}^{2}$, which results in a value of 0.611 . The GoF value can be interpreted as large fit if it has a value of at least 0.36 (IRMA, 2019). Table 5 reveals all effects of the proposed hypotheses analyzed by PLS-SEM.

\section{Moderation of Knowledge and Islamic Religious Belief on Perceived Risk, Satisfaction, and Trust}

Only perceived risk based on knowledge can significantly affect trust in halal-labeled drugs $(\beta=$ $0.164, \mathrm{p} \leq 0.05)$. With knowledge, perceived risk can lead to increased trust. Meanwhile, Islamic religious belief itself does not contribute to this influence. Although this study's knowledge acts as moderation, it is still in line with Hannan (2014) who studied the direct effect. Consumers with good knowledge might have known that halal-labeled drugs have been assured free from negative things, thus willing to take risk to trust the product.
Perceived risk can also significantly affect satisfaction $(\beta=0.483, p \leq 0.05)$. There is an effect that perceived risk can increase satisfaction. Perceived risk usually can decrease satisfaction unless there is a strong motivation to break through the perceived risk (Johnson et al. 2008; Al-Ansi et al. 2019). The result illustrates that respondents in general already have the awareness to use halal-labeled drugs to obtain personal satisfaction. If perceived risk is based on the Islamic religious belief, satisfaction will also be affected significantly $(\beta=0.221$, $p \leq 0.05$ ). There is an effect of increasing satisfaction, but not as strong as when without moderation of Islamic religious belief. Islamic religious belief tends to weaken the effect of perceived risk on satisfaction. Halal logo is only significant to consumers with high level of religiosity, however not all muslim respondents are at that level (Bakar et al. 2013).

\section{Moderation of Knowledge and Previous Use Experience on Satisfaction, Trust, and Intention to Use}

\section{The effect of satisfaction}

Satisfaction can affect trust in halal-labeled drugs significantly $(\beta=0.832, p \leq 0.05)$. The existence of satisfaction can increase trust to halal-labeled drugs. This effect is in accordance with the researches studied by Story and Hess (2006), Dabholkar and Sheng (2012), and Hannan (2014).

When satisfaction is based on knowledge, it can significantly affect trust in halal-labeled drugs $(\beta=$ $-0.135, p \leq 0.05$ ). Satisfaction is an aspect that leads to a functional connection, while trust leads to a personal connection (Story and Hess, 2006). A person feels satisfied with a halal-labeled drug because of its real functionality as a drug proven as halal-certified, which can fulfill religious sharia. Meanwhile, trust which leads to a personal connection tends to be subjective. Thus, when satisfaction with halal-labeled drugs has been based on logical objective knowledge, the subjectivity will disappear and impact the decrease of trust level. Other study such as Rahman et al. (2015) also found that in certain case knowledge may have negative direction on consumer attitude towards halal cosmetics, although its significance is still questionable. Attitude can be dynamically changed depending on feeling, emotion, opinion, and belief, thus it tends to be subjective, as well as trust. 
Table 5. The test results of all proposed effects

\begin{tabular}{llccc}
\hline Effects & $\begin{array}{c}\text { Original } \\
\text { Sample }\end{array}$ & $\begin{array}{c}\text { Standard } \\
\text { Deviation }\end{array}$ & p-Values & Status \\
\hline H1a $:$ Perceived risk $\rightarrow$ Satisfaction & 0.483 & 0.054 & $0.000^{* *}$ & Accepted \\
H1b $:$ Perceived risk $\times$ Islamic religious belief $\rightarrow$ Satisfaction & 0.221 & 0.076 & $0.016^{* *}$ & Accepted \\
H2a $:$ Perceived risk $\rightarrow$ Trust & -0.217 & 0.128 & 0.121 & Rejected \\
H2b $:$ Perceived risk $\times$ Islamic religious belief $\rightarrow$ Trust & -0.043 & 0.185 & 0.819 & Rejected \\
H2c $\quad:$ Perceived risk $\times$ Knowledge $\rightarrow$ Trust & 0.164 & 0.033 & $0.001^{* *}$ & Accepted \\
H3a $:$ Satisfaction $\rightarrow$ Trust & 0.832 & 0.085 & $0.000^{* *}$ & Accepted \\
H3b $:$ Satisfaction $\times$ Knowledge $\rightarrow$ Trust & -0.135 & 0.030 & $0.001^{* *}$ & Accepted \\
H4a $:$ Satisfaction $\rightarrow$ Intention to use & -0.451 & 0.215 & $0.062^{*}$ & Accepted \\
H4b $:$ Satisfaction $\times$ Previous use experience $\rightarrow$ Intention to use & 0.363 & 0.166 & $0.054^{*}$ & Accepted \\
H4c $:$ Satisfaction $\times$ Knowledge $\rightarrow$ Intention to use & 0.233 & 0.111 & $0.062^{*}$ & Accepted \\
H5 $\quad:$ Satisfaction $\rightarrow$ Intention to recommend & 0.186 & 0.051 & $0.005^{* *}$ & Accepted \\
H6a $:$ Trust $\rightarrow$ Intention to use & 0.814 & 0.178 & $0.001^{* *}$ & Accepted \\
H6b $:$ Trust $\times$ Previous use experience $\rightarrow$ Intention to use & -0.122 & 0.112 & 0.303 & Rejected \\
H6c $\quad:$ Trust $\times$ Knowledge $\rightarrow$ Intention to use & -0.151 & 0.083 & $0.100^{*}$ & Accepted \\
H7 $\quad:$ Trust $\rightarrow$ Intention to recommend & 0.127 & 0.069 & $0.095^{*}$ & Accepted \\
H8 $\quad:$ Intention to use $\rightarrow$ Intention to recommend & 0.517 & 0.046 & $0.000^{* *}$ & Accepted \\
\hline Note: ${ }^{*}:$ Significant at $5 \%$ level; ${ }^{*}=$ Significant at $10 \%$ & & & &
\end{tabular}

In its effect on intention to use, naturally, satisfaction can influence intention to use significantly ( $\beta=-0.451$; $\mathrm{p} \leq 0.10$ ). The existence of satisfaction can actually reduce the respondent's intention to use halal-labeled drugs. Respondents who feel satisfied and think that halal-labeled drugs feel more satisfying than drugs without halal label, does not mean that they are triggered to think about using halal-labeled drugs.

When satisfaction is facilitated by adequate knowledge, it can significantly influence the intention to use halallabeled drugs $(\beta=0.233 ; p \leq 0.1)$. Knowledge is able to strengthen the effect of satisfaction, which leads to an increase in intention to use. In this study, although knowledge does not directly affect the intention to use, this is still in line with Kusuma and Untarini (2014) who found that good product knowledge can increase purchase intention. Consumers with high level of knowledge will be more precise and efficient in processing and responding to information as a basis for purchasing decisions (Ekawati, 2014).

Previous experience on using halal-labeled drugs can also significantly influence satisfaction with the intention to use halal-labeled drugs $(\beta=0.363 ; \mathrm{p} \leq$ $0.1)$. It is able to strengthen the effect of satisfaction on intention to use. In line with Fang et al. (2014), a person who has previously used halal-labeled drugs and felt happy during usage, is very likely to make repeated purchase or use of halal-labeled drugs. The data shows that $68.37 \%$ of respondents have bought or used halal-labeled drugs. With this reasonably balanced proportion, it is expected to represent the different experiences of respondents, thus this moderation can more accurately explain the model.

The effect of trust

Trust significantly affects intention to use halal-labeled drugs $(\beta=0.814, p \leq 0.05)$. There is an effect that trust can increase intention to use. This effect is in accordance with the previous research conducted by Dabholkar and Sheng (2012), Lassoued et al. (2015), Semuel and Chandra (2014), and Tasin (2017).

Moderation of previous use experience does not have a significant effect, but only knowledge has a significant effect. Knowledge can significantly affect trust towards intention to use $(\beta=-0.151 ; p \leq 0.1)$. This negative direction is not in line with the study conducted by Ekawati et al. (2014) and Kusuma and Untarini (2014), where the presence of knowledge should be able to increase the intention to use. In this study, objective knowledge covers covers the insight that the halal logo does not indicate that the efficacy and safety are better than another similar drug without a halal logo. Drugs without halal logo are those not yet submitted for halal certification. As long as a drug has obtained marketing authorization approval from BPOM RI, then the drug's safety, efficacy, and quality can be guaranteed, 
regardless of whether or not the drug has been halalcertified. Both can be trusted in terms of efficacy, quality, and information on packaging, so respondents who trust halal-labeled drugs does not mean they do not trust those without halal logo, and they may think that they do not always have to buy it.

\section{Effect of Satisfaction, Trust, and Intention to Use Towards Intention to Recommend}

Satisfaction can significantly affect intention to recommend $(\beta=0.186, p \leq 0.05)$ and trust also has a significant direct effect to intention to recommend halallabeled drugs $(\beta=0.127, \mathrm{p} \leq 0.1)$. Both satisfaction and trust can increase intention to recommend halallabeled drugs. These direct effects are also in line with the previous studies conducted by Al-Ansi et al. (2019) and supported by the commitment process model by Story and Hess (2006), in which both satisfaction and trust are required to create recommendation intention as a form of loyalty.
Intention to use can significantly influence intention to recommend halal-labeled drugs $(\beta=0.517, \mathrm{p} \leq 0.05)$. There is an effect that intention to use can increase intention to recommend halal-labeled drugs. Story and Hess (2006) and Al-Ansi et al. (2019) stated that both satisfaction and trust have direct positive effect on intention to recommend. Based on the concept of logic, before someone whose strong connection with a product is going to have an intention to recommend, it should be preceded by an intention to buy or use.

\section{Indirect Effects}

Table 6 shows some of the indirect effects that are considered important. The targeted key output is intention. When consumers already have the intention, they will be triggered to try to find, buy, and use halallabeled drugs. Further, they can also recommend halallabeled drugs to other people.

Table 6. Indirect effects

\begin{tabular}{|c|c|c|c|}
\hline Effects & $\begin{array}{l}\text { Original } \\
\text { Sample }\end{array}$ & $\begin{array}{l}\text { Standard } \\
\text { Deviation }\end{array}$ & p-Values \\
\hline \multicolumn{4}{|l|}{ Indirect effects to intention to recommend through the satisfaction path } \\
\hline Perceived risk $\rightarrow$ Satisfaction $\rightarrow$ Intention to use $\rightarrow$ Intention to recommend & -0.113 & 0.054 & 0.062 \\
\hline $\begin{array}{l}\text { Perceived risk } \times \text { Islamic religious belief } \rightarrow \text { Satisfaction } \rightarrow \text { Intention to use } \rightarrow \\
\text { Intention to recommend }\end{array}$ & -0.052 & 0.039 & 0.216 \\
\hline Perceived risk $\rightarrow$ Satisfaction $\rightarrow$ Intention to recommend & 0.090 & 0.029 & $0.010^{* *}$ \\
\hline Perceived risk $\times$ Islamic religious belief $\rightarrow$ Satisfaction $\rightarrow$ Intention to recommend & 0.041 & 0.016 & $0.024^{* *}$ \\
\hline \multicolumn{4}{|l|}{ Indirect effects to intention to recommend through the trust path } \\
\hline Perceived risk $\rightarrow$ Trust $\rightarrow$ Intention to use $\rightarrow$ Intention to recommend & -0.091 & 0.063 & 0.176 \\
\hline $\begin{array}{l}\text { Perceived risk } \times \text { Islamic religious belief } \rightarrow \text { Trust } \rightarrow \text { Intention to use } \rightarrow \text { Intention to } \\
\text { recommend }\end{array}$ & -0.018 & 0.083 & 0.831 \\
\hline Perceived risk $\times$ Knowledge $\rightarrow$ Trust $\rightarrow$ Intention to use $\rightarrow$ Intention to recommend & 0.069 & 0.014 & $0.000^{* *}$ \\
\hline Perceived risk $\rightarrow$ Trust $\rightarrow$ Intention to recommend & -0.027 & 0.019 & 0.183 \\
\hline Perceived risk $\times$ Islamic religious belief $\rightarrow$ Trust $\rightarrow$ Intention to recommend & -0.006 & 0.025 & 0.828 \\
\hline Perceived risk $\times$ Knowledge $\rightarrow$ Trust $\rightarrow$ Intention to recommend & 0.021 & 0.013 & 0.129 \\
\hline \multicolumn{4}{|l|}{ Indirect effects to intention to recommend through the satisfaction path crossing trust } \\
\hline $\begin{array}{l}\text { Perceived risk } \rightarrow \text { Satisfaction } \rightarrow \text { Trust } \rightarrow \text { Intention to use } \rightarrow \text { Intention to } \\
\text { recommend }\end{array}$ & 0.169 & 0.034 & $0.001^{* *}$ \\
\hline $\begin{array}{l}\text { Perceived risk } \times \text { Islamic religious belief } \rightarrow \text { Satisfaction } \rightarrow \text { Trust } \rightarrow \text { Intention to use } \\
\rightarrow \text { Intention to recommend }\end{array}$ & 0.078 & 0.032 & $0.038^{* *}$ \\
\hline Perceived risk $\rightarrow$ Satisfaction $\rightarrow$ Trust $\rightarrow$ Intention to recommend & 0.051 & 0.030 & 0.125 \\
\hline $\begin{array}{l}\text { Perceived risk } \times \text { Islamic religious belief } \rightarrow \text { Satisfaction } \rightarrow \text { Trust } \rightarrow \text { Intention to } \\
\text { recommend }\end{array}$ & 0.023 & 0.013 & 0.105 \\
\hline
\end{tabular}

Note: ${ }^{* *}=$ Significant at $5 \%$ level 
Based on the result, various paths can be taken to arrive at the intention to recommend. Through the satisfaction path, intention to recommend halal-labeled drugs can be achieved without intention to use. This is in line with the study conducted by Al-Ansi et al. (2019). However, when going through the satisfaction path that also crosses trust, there is intention to use before recommending halal-labeled drugs. Trust is needed to trigger intention to use of a product (Dabholkar and Sheng, 2012; Semuel and Chandra, 2014; Lassoued et al. 2015; Tasin, 2017). The effect supported by Islamic religious belief is also significant, but it does not mean that Islamic religious belief can help strengthen the basic effect through satisfaction. In fact, the existence of Islamic religious belief tends to weaken the basic effect indicated by a lower factor loading. As previously explained, a muslim does not always have high Islamic religiosity. Unfortunately, this research does not take religiosity into account. Through the trust path, knowledge is needed to ensure the model sustainability through intention to use until intention to recommend. However, knowledge does not help strengthen the effect towards intention to recommend if without passing intention to use.

\section{Managerial Implications}

The study discovered that consumer preference towards halal-labeled drugs in Indonesia requires knowledge and previous use experience. However, the current issue is the lack of basic knowledge on drugs and halal-labeled drugs, especially in the younger generation. This is very unfortunate because they are the future of Indonesia. With good level of knowledge, it will be easier to bring the society to the preference of halal-labeled drugs in the future. When the consumers are used to choosing halal-labeled drugs, and having positive experiences, they can be trigerred to repurchase or reuse halal-labeled drugs. The pharmaceutical industry and the government can do efforts to increase consumer knowledge. The government has stipulated several regulations, however there has never been any socialization for the public to increase their knowledge. The pharmaceutical industry can also contribute, not only by selling halal-labeled drugs to comply with regulation, but can also give socialization to increase consumer knowledge. However, increasing Indonesian consumers' knowledge should also be balanced with efforts to raise consumer awareness by highlighting the importance of halal-labeled drugs from religious perspective. It is hoped that the increased consumer knowledge can have chain implication to consumers themselves to recommend halal-labeled drugs to others.

In line with current regulations, the pharmaceutical industry have to prepare and implement halal certification on their drug products, whatever it takes. Assuring halal status of drug products certainly requires high effort, considering that some raw materials and/or finished products are imported from foreign countries. The government has updated the deadline for fulfilling halal certification of drug products, and the remaining time should be utilized by the industry to prepare everything. The industry may prioritize the most commonly purchased therapeutic group, such as analgesics-antipyretics, cough and/or flu drugs, antacids, oral antibiotics, and opioid analgesics, for halal certification, as well as to make consumers familiar with the halal-labeled drug by increasing the exposure. Prioritization can help the pharmaceutical industry to prepare the strategy in preparing and implementing halal certification on drug products. Certification on other drug products can be done afterwards.

\section{CONCLUSIONS AND RECOMMENDATIONS}

\section{Conclusions}

The study discovered that there are two main paths to support the model continuity, which are satisfaction path and trust path. Through the satisfaction path, the perceived risk can naturally increase respondents' satisfaction towards halal-labeled drugs. Support from Islamic religious belief is also significant, but the effect is not stronger than the basic effect. Furthermore, the satisfaction that has been built cannot lead towards the intention to use unless facilitated by knowledge or previous experience on using halal-labeled drugs. A person who already has a sense of satisfaction also makes it possible to foster a sense of trust on the halallabeled drugs, so that further it can also continue crossing via the trust path. The perceived risk will increase the trust towards halal-labeled drugs only if facilitated by adequate knowledge through the trust path. A person who already trust will directly have intention to use halal-labeled drugs without requiring other triggers. 
Intention to use as the result of both paths allows the chain to continue to the intention to recommend. Both satisfaction and trust have direct effect to the intention to recommend. Knowledge and previous use experience are the supporting factors required to reach consumers' intention. However, increasing knowledge of Indonesian consumers should also be balanced with efforts to raise consumer awareness by highlighting the importance of halal-labeled drugs from religious perspective. Both government and the pharmaceutical industry can together improve the basic knowledge of Indonesian people on halal-labeled drugs. Marketing activity, public socialization, advertising, or other media can be used to deliver the information.

\section{Recommendations}

This study might be a pioneer in the development of conceptual model based on perceived risk approach in the context of halal-labeled drugs adapted from previous studies which use other product as the research object, therefore there are still many things needed to be refined. It is suggested that further research can involve larger number of respondents, and more even demographic profile. In this study, the level of religiosity was not measured. However, it is interesting to discover the influence of consumer religiosity level, because someone with Islamic religious belief does not always have high religiosity, and is triggered to choose halal-labeled drugs. Moreover, the knowledge that can have different moderation effects can be explored more deeply at different stages.

\section{REFERENCES}

Al-Ansi A, Olya HGT, Han H. 2019. Effect of general risk on trust, satisfaction, and recommendation intention for halal food. International Journal Hospital Management 83: 210-219. https://doi. org/10.1016/j.ijhm.2018.10.017.

Annabi CA, Wada SM. 2016. Halal Pharmaceutical Industry in Nigeria: A bitter pill to swallow. Journal of Emerging Economies and Islamic Research 4(2): 1-12.

Bakar A, Lee R, Rungie C. 2013. The effects of religious symbols in product packaging on Muslim consumer responses. Australasian Marketing Journal 21(3): 198-204. https://doi. org/10.1016/j.ausmj.2013.07.002.
Barclay D, Higgins C, Thompson R. 1995. The Partial Least Squares (PLS) approach to causal modeling: personal computer adoption and use as an illustration. Technology Studies 2(2): 285309.

[BPOM RI] Badan Pengawas Obat dan Makanan Republik Indonesia. 2019. Cek Produk BPOM. http://cekbpom.pom.go.id/. [2019 Oct 12].

Chin WW. 1998. The Partial Least Squares Approach to Structural Equation Modeling in Modern Methods for Business Research. Marcoulides GA, editor. Mahwah: Lawrence Erlbaum Associates, Inc.

Chin WW, Newsted PR. 1999. Structural Equation Modeling: Analysis with Small Samples Using Partial Least Square. Di dalam: Hoyle RH, editor. Statistical Strategies for Small Sample Research. Thousand Oaks: SAGE Publications.

Dabholkar PA, Sheng X. 2012. Consumer participation in using online recommendation agents: Effects on satisfaction, trust, and purchase intentions. The Service Industries Journal 32(9): 14331449. https://doi.org/10.1080/02642069.2011.6 24596.

Dowling GR, Staelin R. 1994. A model of perceived risk and intended risk-handling activity. Journal of Consumer Research 21(1): 119-134.

Ekawati M, Kumadji S, Kusumawati A. 2014. Pengaruh electronic word of mouth terhadap pengetahuan konsumen serta dampaknya pada keputusan pembelian (Survei pada Followers Account Twitter@WRPdiet).Jurnal Administrasi Bisnis 14(2): 1-8.

Famiza AN, Samsinar KN, Kursimah H, Firdaus RBR. 2017. Buying halal pharmaceutical products: Do consumers have imperfect knowledge? Pertanika 25(2017):153-164.

Fang Y, Qureshi I, Sun H, McCole P, Ramsey E, Lim KH. 2014. Trust, satisfaction, and online repurchase intention: the moderating role of perceived effectiveness of e-commerce institutional mechanisms. MIS Quarterly 38(2): 407-427.

Fornell C, Larcker DF. 1981. Evaluating structural equation models with unobservable variables and measurement error. Journal of Marketing Research 18(1):39-50. https://doi. org/10.1177/002224378101800104.

Giese JL, Cote JA. 2000. Defining consumer satisfaction. Academy of Marketing Science Review 1(1):1-22. 
Hannan S. 2014. Model pemasaran hubungan pada jasa profesi: studi empiris pada industri jasa surveyor independen di Indonesia. [dissertation]. Bogor: Institut Pertanian Bogor.

Hicks D, Pivarnik L, McDermott R. 2008. Consumer perceptions about seafood - an Internet survei. Journal of Foodservice 19(4): 213-226. https:// doi.org/10.1111/j.1748-0159.2008.00107.x.

[IRMA] Information Resources Management Association. 2019. Cloud Security: Concepts, Methodologies, Tools, and Applications: Concepts, Methodologies, Tools, and Applications. Hershey: IGI Global.

Johnson MS, Sivadas E, Garbarino E. 2008. Customer satisfaction, perceived risk and affective commitment. Journal of Services Marketing 22(5): 353-362. https://doi. org/10.1108/08876040810889120.

Kusuma ID, Untarini N. 2014. Pengaruh pengetahuan produk terhadap niat beli dengan sikap sebagai variabel intervening. Jurnal Ilmu Manajemen 2(4): 1573-1583.

Lassoued R, Hobbs JE, Micheels ET, Zhang DD. 2015. Consumer trust in chicken brands: a structural equation model. Canadian Journal of Agricultural Economics 63(4): 621-647. https:// doi.org/10.1111/cjag.12082.

Lien CH, Wen MJ, Huang LC, Wu KL. 2015. Online hotel booking: The effects of brand image, price, trust and value on purchase intentions. Asia Pacific Management Review 20(4):210-218. https://doi.org/10.1016/j.apmrv.2015.03.005.

[LPPOM MUI] Lembaga Pengkajian Pangan, Obatobatan, dan Kosmetika Majelis Ulama Indonesia. 2019. Pencarian Produk Halal. http://www. halalmui.org/mui14/index.php/main/ceklogin_ halal/produk_halal_masuk/.[2019 Oct 12].

[Menag RI] Menteri Agama Republik Indonesia. 2019. Peraturan Menteri Agama Republik Indonesia Nomor 26 Tahun 2019 tentang Penyelenggaraan Jaminan Produk Halal. Jakarta: Kementerian Hukum dan Hak Asasi Manusia.
Mowen JC, Minor M. 2002. Perilaku Konsumen Jilid 2. Yahya DK, translator; Mahanani N, editor. Jakarta: Erlangga. Translation from: Consumer Behavior. 5th Ed.

Nafis MC. 2019. Konsep halal dan thayyib beserta implementasinya di Indonesia. Journal of Halal Product and Research 2(1):1-5.

Nofianti KA, Rofiqoh SNI. 2019. Kesadaran dan logo halal: apakah menentukan minat beli? (Studi pada Praktisi Bisnis UMKM di Gresik). Journal of Halal Product and Research 2(1): 16-24.

[Presiden RI] Presiden Republik Indonesia. 2014. Undang-undang Nomor 33 Tahun 2014 tentang Jaminan Produk Halal. Jakarta: Kementerian Sekretariat Negara Republik Indonesia.

Rahman AA, Asrarhaghighi E, Rahman SA. 2015. Consumer and halal cosmetic products: knowledge, religiosity, attitute and intention. Journal of Islamic Marketing 6(1): 148-163. https://doi.org/10.1108/JIMA-09-2013-0068.

Rambe YM, Afifuddin S. 2012. Pengaruh pencantuman label halal pada kemasan mie instan terhadap minat pembelian masyarakat muslim (Studi Kasus pada Mahasiswa Universitas Al Washliyah, Medan). Jurnal Ekonomi dan Keuangan 1(1): 36-45.

Semuel H, Chandra SS. 2014. The Analysis of corporate social responsibility implementation effects towards price fairness, trust and purchase intention at oriflame cosmetics product in Surabaya. Procedia - Social and Behavioral Sciences 155:42-47. https://doi.org/10.1016/j. sbspro.2014.10.253.

Story J, Hess J. 2006. Segmenting customerbrand relations: beyond the personal relationship metaphor. Journal of Consumer Market 23(7): 406-413. https://doi. org/10.1108/07363760610712948.

Tasin NB. 2017. Factors influencing customer's trust in online shopping among executives in a Bank. Malaysian Journal of Social Sciences and Humanities 2(3): 47-60. 